\title{
COMPUTER ASSISTED COMPOUND DIE DESIGN: A CASE STUDY
}

\author{
Sneha S.Pawar ${ }^{1}$, R.S.Dalu ${ }^{2}$ \\ ${ }^{1}$ M.Tech. student, Production Engineering, Govt. College of Engineering, Amravati, (M.S.) India. \\ ${ }^{2}$ Professor \& Head, Mechanical Engineering Department, Govt. College of Engineering, Amravati, (M.S.) India
}

\begin{abstract}
A compound die set for a blanking, drawing and punching operations are in many cases is very complex and expensive device. It is time consuming design die set by combining these three operations manually. This paper presents a Computer assisted design method to design compound die set for downlight housing. The design calculations take account of the quality of the workpiece material and they determine the optimal size for the die punch sets. The proposed method can be used for any configuration of the parts which need to be processed. The design calculations are verified by using manual die design process.
\end{abstract}

Keywords: Compound die set, computer assisted die design, CAD.

\section{INTRODUCTION}

The evolution of products, dictated by the necessity to survive in the market, requires changes in manufacturing processes. This requires an integrated approach of constructive aspects, technological, organizational and management of the development stages in order to reduce time and cost of the new products. Design activity has an important role in developing a new product. Design time being very often decisive in terms of the marketing time of the product. Computer assisted design brings immediate benefits, which consists of a computer process that eliminates repetitive tasks and sometimes complicated calculations. Computer assisted computing minimizes the efforts of designing a new variety of product within the same family of parts (8).

This paper presents computer assisted method to design compound dies for down light housing. Computer program developed in Visual studio containing values corresponding to different characteristics of 3D models.

\section{COMPUTER ASSISTED DIE DESIGN (CADD)}

Computer assisted design is not a new concept for engineers. Even since antiquity computer assisted on was used to design buildings, weapons, becoming indispensable later in various fields of industry such as footwear industry, cloths industry, et.al.

In mechanical field the computer assisted design presents interest for designing families of parts, a family of pieces that represents a set of parts like each other as shape, but different in their size, the basic topology being the same for each family member. Computer assisted design assumes the use of relationships defined by means of parameters which define or constrain the features of designed product. By connecting various characteristics of the designed model with the corresponding parameters from relationships, becomes possible that any element of the projected model to be automatically changed, making it a flexible model.
Now a day's development of computer technology provides powerful tools which allow solving complex algorithms for computer assisted design. Recent versions of most CAD application allow an easily modification of primary parameters, resulting an immediately transformation of 3D model. In terms on how to achieve the computer assisted design are multiple choices to define the constraints of each parameter.

The first option is to enter manually the necessary data in a working module specified to CAD application. A model for another family member is obtained by manually changing the input values. The main advantage of this method consists in the possibility of making any modification according to the necessities. The disadvantage is due to the high amount of data that needs to be input manually. Another option involves the development of a computer program in different programming fields, where key parameters are introduced as variables (8).

These variables are required as input when running the program is launched and are used in various mathematical expressions, so that after each running program, parameters are obtained for each family member with different geometrical characteristics, maintaining the relations between different entities as well. Parameters are saved in program which can be "read" or have links with model parameters from CAD application. The advantage consists once that the computer program supports any modification easily, being realized with a minimized workload and also the fact that the obtained model is without errors, whenever data input are adjusted. One disadvantage can be that manual change is restrictive in condition of respecting the constraints between element, any changes can be performed only by a subsequent run of the program that generates a new set of parameters. Another disadvantage, especially for complex models with large number of parameters constrained, is the fact that must be solved a large number of equations by numerical methods to define constraints between parameters. The main step for computer assisted die design is shown in figure 1. 


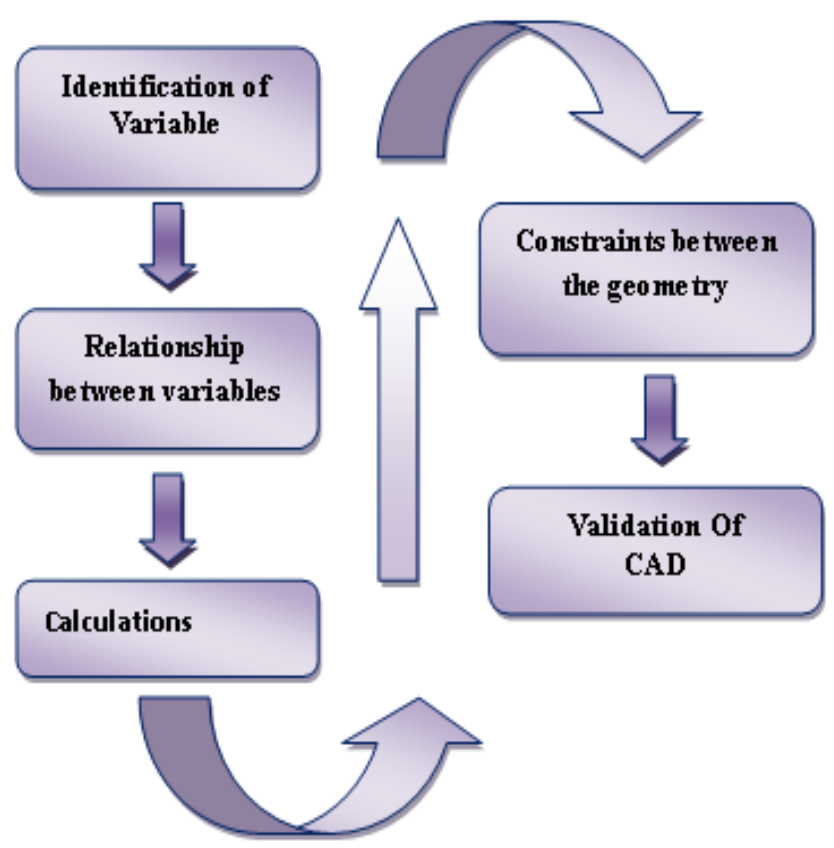

Fig 1:-Main step in computer assisted die design

\section{CASE STUDY}

This paper presents the computer assisted die design of a compound dies for Downlight housing for Onkar Industry Nagpur. Based on workpiece dimensions and using mathematical relationships presented in the developed computer program in .net technology, tool- Visual studio, langue-C\#, project type-Window application which allows the determination of constructive parameters for the elements of compound dies. A windows application is an application that runs on windows desktop. Windows applications will have graphical user interface (GUI). Because of GUI, designing the application will be easy and fast. Output window shown in figure $32 \mathrm{D}$ View of downlight housing is given in figure 2 .

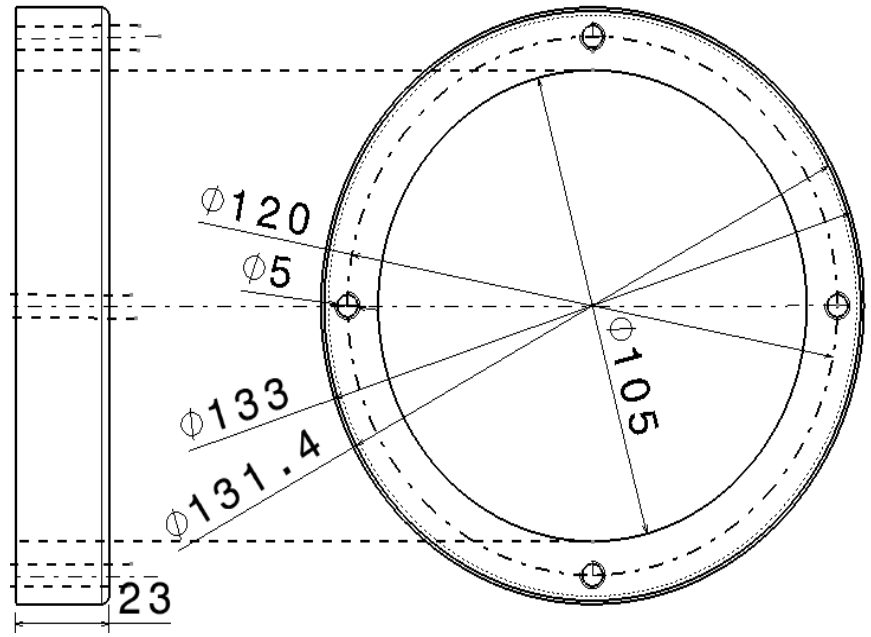

Fig 2: Downlight housing assembly

\subsection{Comparison between output of Computer}

\section{assisted Die Design and Manual Die Design}

There are eight input parameters which are shown in table 1. The output of computer assisted die design and manual die design has been compared and given in table 2.Comparison shows that a variation in dimensions is very less.

Table 1: Input Parameters

\begin{tabular}{|l|l|l|}
\hline \multicolumn{4}{|l|}{ Input Parameters : } \\
\hline Sr.no & Name of I/p parameter & Dimension \\
\hline 1 & Cup Diameter & $133 \mathrm{~mm}$ \\
\hline 2 & Cup Height & $23 \mathrm{~mm}$ \\
\hline 3 & Thickness & $0.8 \mathrm{~mm}$ \\
\hline 4 & Shearing strength & $400 \mathrm{~N} / \mathrm{mm}^{2}$ \\
\hline 5 & Yield strength & $427 \mathrm{~N} / \mathrm{mm}^{2}$ \\
\hline 6 & Punch diameter-A $(105 \mathrm{~mm})$ & $105 \mathrm{~mm}$ \\
\hline 7 & Punch diameter-B $(5 \mathrm{~mm})$ & $5 \mathrm{~mm}$ \\
\hline 8 & Number of row & 1 \\
\hline
\end{tabular}

Table2: Comparison between outputs of Computer assisted die design and Manual die design

\begin{tabular}{|l|l|l|l|}
\hline Sr.no & Name of O/P parameter & Computer assisted die design & Manual die design \\
\hline & Blanking die & & \\
\hline 1 & Strip layout -Economy Factor (\%) & $67.92 \%$ & $67.61 \%$ \\
\hline 2 & Material utilization & & \\
& -Material utilization (\%) & $67.14 \%$ & $66 \%$ \\
& -Scrap (\%) & $32.86 \%$ & $33 \%$ \\
\hline 3 & Diameter of die (mm) & $191.36 \mathrm{~mm}$ & $191.13 \mathrm{~mm}$ \\
\hline 4 & Cutting Force (ton) & $19.26 \mathrm{~mm}$ & 19.20 ton \\
\hline 5 & Die Block Design & & \\
& -Perimeter (mm),Thickness, Height ,Length & $602.03 \mathrm{~mm}, 27 \mathrm{~mm}, 2.7 \mathrm{~mm}, 40.5600 \mathrm{~mm}, 27 \mathrm{~mm}, 2.7 \mathrm{~mm}, 40.5 \mathrm{~mm}$ \\
\hline
\end{tabular}




\begin{tabular}{|c|c|c|c|}
\hline & $-\mathrm{A}$ & $\mathrm{mm}$ & \\
\hline 6 & Punch Design & Safe for crushing & Safe for crushing \\
\hline 7 & $\begin{array}{l}\text { Thickness of plates } \\
\text {-Die Plate (mm),Top Plate (mm) ,Bottom } \\
\text { Plate } \\
\text {-Punch Holder Plate, Stripper plate ,Thrust } \\
\text { plate } \\
\text {-Working area WA, WA1,WA2 } \\
\text {-Guide Pillar (mm) }\end{array}$ & $\begin{array}{l}26.8 \mathrm{~mm}, 40.21 \mathrm{~mm}, 46.91 \mathrm{~mm} \\
20.1 \mathrm{~mm}, 13.4 \mathrm{~mm}, 8.5 \mathrm{~mm} \\
53.61 \mathrm{~mm}, 298.71 \mathrm{~mm}, 298.71 \mathrm{~mm} \\
33 \mathrm{~mm}\end{array}$ & $\begin{array}{l}26.7 \mathrm{~mm}, 40.05 \mathrm{~mm}, 46.72 \mathrm{~mm} \\
20 \mathrm{~mm}, 13.35 \mathrm{~mm}, 8.5 \mathrm{~mm} \\
53.4 \mathrm{~mm}, 297.8 \mathrm{~mm}, 298.7 \mathrm{~mm} \\
33 \mathrm{~mm}\end{array}$ \\
\hline & Drawing die & & \\
\hline 1 & Blank Size (mm) & $191.49 \mathrm{~mm}$ & $191 \mathrm{~mm}$ \\
\hline 2 & Percentage Reduction (\%) & $30.55 \%$ & $30.37 \mathrm{~mm}$ \\
\hline 3 & Drawing Force (ton) & 11.27 ton & 11.21 ton \\
\hline 4 & Blank Holding Force (ton) & 3.76 ton & 4 ton \\
\hline 5 & $\begin{array}{l}\text { Die Clearance } \\
\text {-Die Clearance ,Punch Diameter ,Die } \\
\text { Diameter }\end{array}$ & $0.88 \mathrm{~mm}, 131.4 \mathrm{~mm}, 131.16 \mathrm{~mm}$ & $1.9 \mathrm{~mm}, 131.4 \mathrm{~mm}, 131.16 \mathrm{~mm}$ \\
\hline 6 & Number of Draw Required & 1 & 1 \\
\hline 7 & Radius on Die $(\mathrm{mm})$ & $3.6 \mathrm{~mm}$ & $3.6 \mathrm{~mm}$ \\
\hline 8 & Radius of the Punch Corner (mm) & $2.4 \mathrm{~mm}$ & $2.4 \mathrm{~mm}$ \\
\hline 9 & Punch Design & Safe for crushing & Safe for crushing \\
\hline 10 & Backup Plate Thickness (mm) & $3 \mathrm{~mm}$ & $3 \mathrm{~mm}$ \\
\hline 11 & Stripping Force (ton) & 0.2 ton & 0.201 ton \\
\hline 12 & 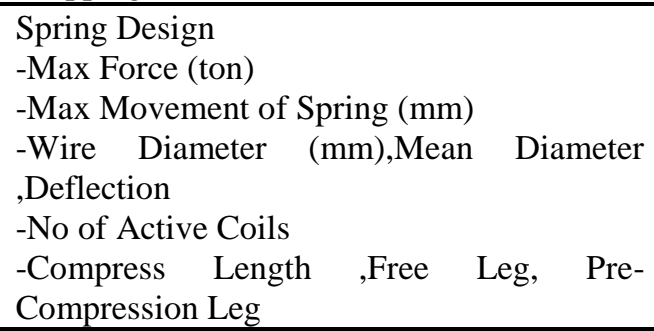 & $\begin{array}{l}0.08 \mathrm{ton} \\
10 \mathrm{~mm} \\
4 \mathrm{~mm}, 18 \mathrm{~mm}, 1.64 \mathrm{~mm} \\
6 \\
30.4 \mathrm{~mm}, 40.4 \mathrm{~mm}, 33.4 \mathrm{~mm} \\
\end{array}$ & $\begin{array}{l}0.0756 \text { ton } \\
10 \mathrm{~mm} \\
4 \mathrm{~mm}, 18 \mathrm{~mm}, 1.64 \mathrm{~mm} \\
6 \\
30.4 \mathrm{~mm}, 40.4 \mathrm{~mm}, 33.4 \mathrm{~mm}\end{array}$ \\
\hline & Punching die & & \\
\hline & Punching Operation- A & & \\
\hline 1 & Punch Diameter $(\mathrm{mm})$ & $105.05 \mathrm{~mm}$ & $105.05 \mathrm{~mm}$ \\
\hline 2 & Die Diameter $(\mathrm{mm})$ & $105.13 \mathrm{~mm}$ & $105.13 \mathrm{~mm}$ \\
\hline 3 & Cutting Force (ton) & 10.56 ton & 10.76 ton \\
\hline 4 & Backup Plate Thickness (mm) & $3 \mathrm{~mm}$ & $3 \mathrm{~mm}$ \\
\hline 5 & $\begin{array}{l}\text { Die Block Design } \\
\text {-Perimeter ,Thickness, Height (mm),Length } \\
\text { - A }\end{array}$ & $\begin{array}{l}330.3 \mathrm{~mm}, 27 \\
\mathrm{~mm}, 40.5 \mathrm{~mm}\end{array}$ & $\begin{array}{l}729.87 \mathrm{~mm}, 27 \mathrm{~mm}, 2.7 \mathrm{~mm}, 40.5 \\
\mathrm{~mm}\end{array}$ \\
\hline 6 & Punch Design & Safe for crushing & Safe for crushing \\
\hline & Punching Operation - B & & \\
\hline 1 & Punch Diameter (mm) & $5.05 \mathrm{~mm}$ & $5.05 \mathrm{~mm}$ \\
\hline 2 & Die Diameter $(\mathrm{mm})$ & $5.13 \mathrm{~mm}$ & $5.13 \mathrm{~mm}$ \\
\hline 3 & Cutting Force (ton) & 0.51 ton & 0.50 ton \\
\hline 4 & Backup Plate Thickness (mm) & 2.03 ton & 2.01 ton \\
\hline 5 & Punch Design & & \\
\hline & Press capacity & 47.08 ton & 47.48 ton \\
\hline
\end{tabular}




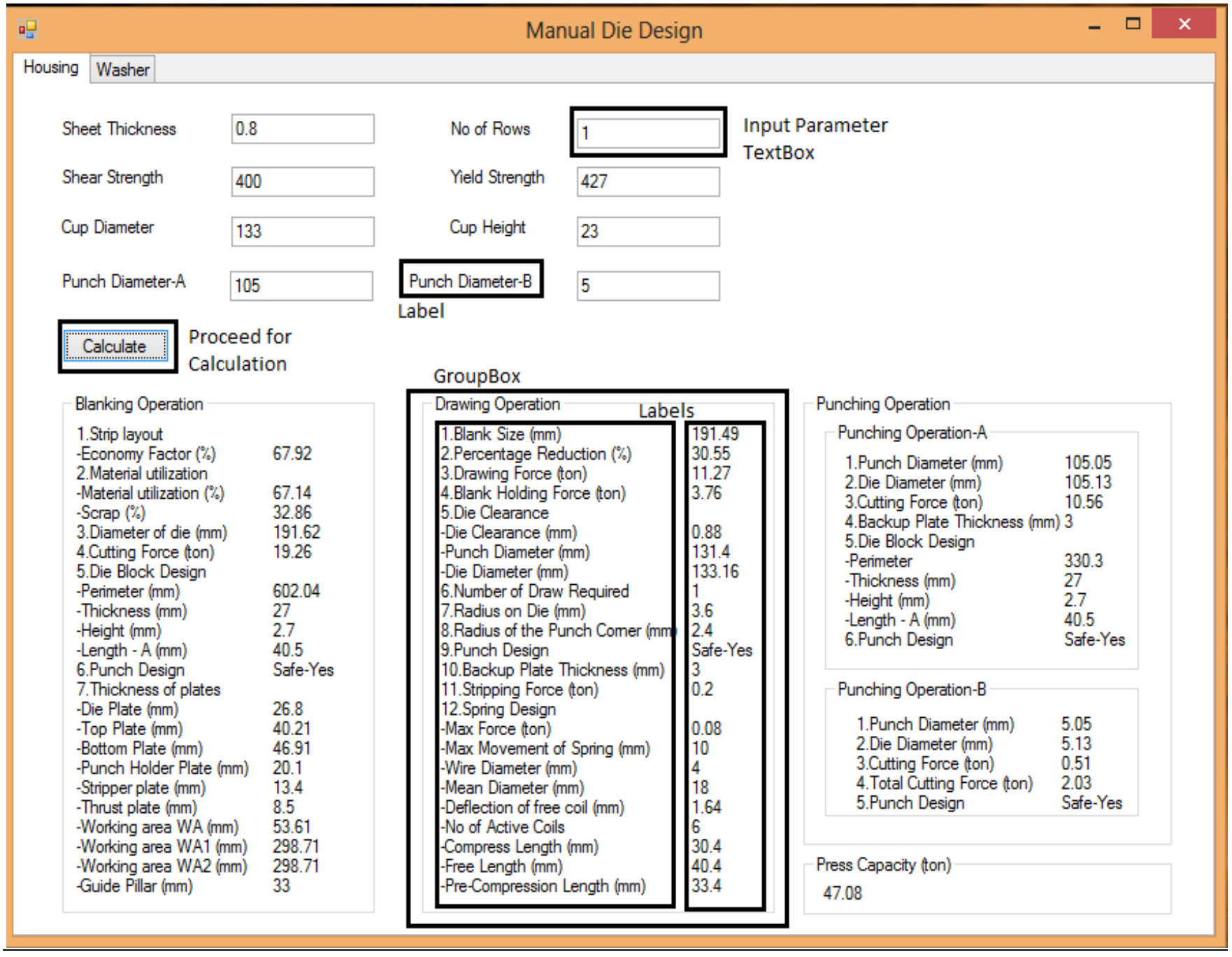

Fig 3:-Output Window

By provide input as table 1 to the program output can be obtained as shown in figure 3 which then can be used to model the 3D assembly (figure 4). Figure 5 and 6 shows, $2 \mathrm{D}$ view of compound die before operation and after operation resp.

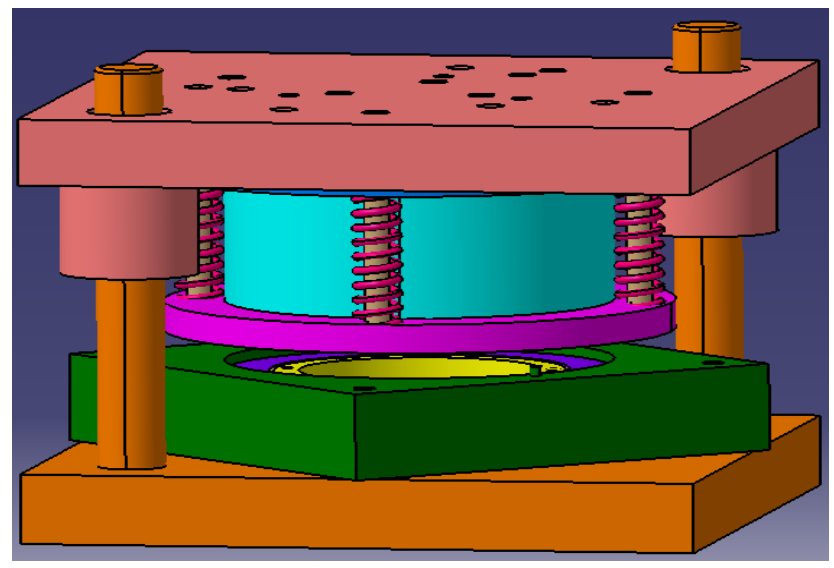

Fig 4:- 3D assembly of housing

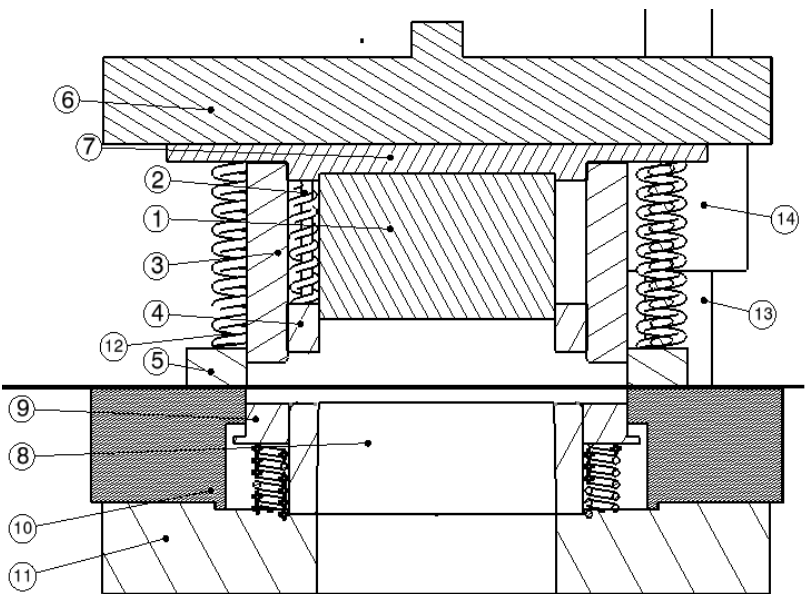

Fig 5: 2D view of Compound dies (Before operation)

Cutting punch-I (1) ,Cutting punch-II(2), Drawing punch(3),Pressure plate-I(4), Pressure plate-II(5),Punch plate(6), Thrust plate(7), Die(8),Ejector plate(9),Die block(10),Die palate (11),Spring(12),pillar(13) 


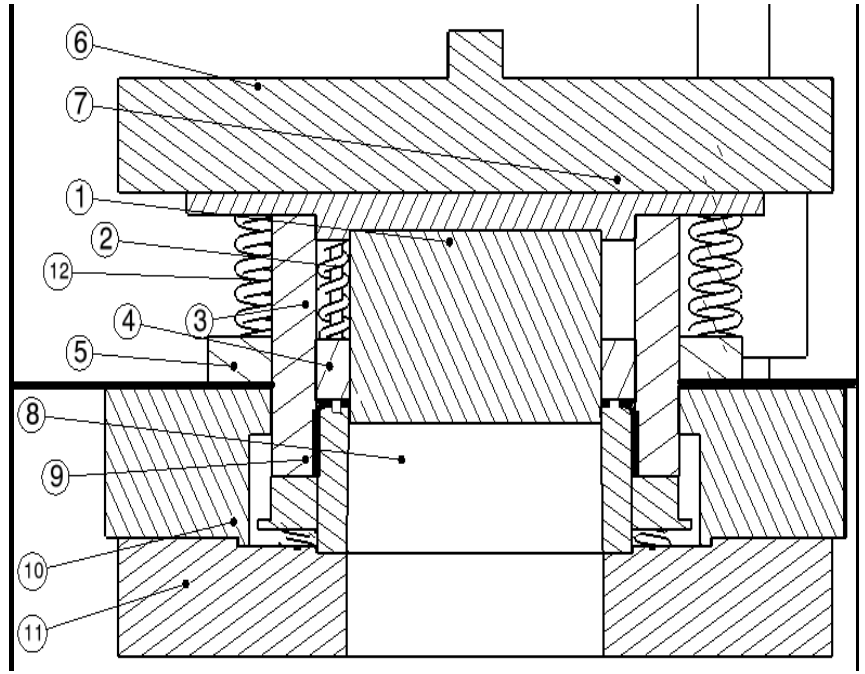

Fig 6: $2 \mathrm{D}$ view of Compound dies (After operation)

\section{CONCLUSIONS}

- The output of computer assisted die design for downlight housing has been verified with the result of manual die design. It has been observed that computer assisted die design method provided high accuracy and consume less time.

- $\quad$ The proposed method CADD can be used to any configuration of the processed workpiece with little modifications.

\section{REFERENCES}

[1] Badrinarayanan S. "Perform and die design problems in metal Forming" Cornell University (1997).

[2] Burton Wilson, Jon Carlson, Brad Cobb, Amber Monceaux, Tyler Ray ,Ron York"Manually operated punch press Design report draft 3"(2008).

[3] Chada Vamshikrishna Reddy, "Computer aided design of sheet metal die assembly utilispro / engineer and mechanica" B.tech. Jawaharlal nehru Technological University, India, (2007).

[4] Hijink J.A.W., T.H.Elndhoven , A.C.H. Van Der WolF "On the design of die-set" annals of the CIRP,vol 24, (1975) .

[5] Lahadotiya Milash Kumar, Kakirde Abhay Dinkar and Pandey Asutosh Kumar "Mini Review on Designing of Press Tools for Sheet Metal Parts" JECET Vol.2.No.3, 650-660, (2013).

[6] Madake Amit D., Naik Vinayak Kulkarni RSwapnil S. "Development of a Sheet-Metal Component with a Forming Die Using CAE Software Tools (Hyper form) For Design Validation and Improvement" International Journal of Modern Engineering Research, Vol. 3, Issue. 3, Pp-1787-1791, (2013).

[7] Mohammad Haider, K. K. Pathak, Geeta Agnihotri "Perform design for near net shape close die gear forging using simulation technique", Archives of Applied Science Research, 2 (6):317-324, (2010).

[8] Stanasel Iulian, florin blaga and ioan radu "Research on parametric design of die punch". Academic journal of manufacturing engineering, vol. 10, issue 1, (2012).

[9] Zabaras Nicholas And akkaram srikanthm "An object-oriented programming approach to the lagrangian fem analysis of large inelastic deformations and metal-forming processes international journal for numerical methods in engineering”. 45,399-445, (1999). 